\title{
Boda-boda, Youth Employment and Globalisation in Uganda
}

By Charles Amone

Kyambogo University P. O. Box 1, Kyambogo-Uganda, Emails: camone@kyu.ac.ug/amonedelcol@yahoo.com

\begin{abstract}
Formerly shunned due its notoriety for facilitating illicit trade and transporting criminals across Uganda's international borders, the boda-boda transport industry gained fame in recent years and has become the second largest employer of youths all over Uganda, after agriculture. Recent scholarship on the bodaboda industry has however, concentrated on the risks embedded in it including high infection rates of HIV among the drivers and the daily accidents reported. Little attention has been paid to the contribution of the industry in youth employment. This paper discusses the role of boda-boda transport industry in solving the problem of unemployment among the youths in Uganda. The author interviewed seventeen boda-boda drivers in Uganda and thirty-four of their family members to establish how this transport business has impacted on employment opportunities, financial independence and globalisation of youths. The study revealed that whereas many youths have dropped out of school to take up the boda-boda business, profits of this trade have facilitated the education of some young people in Uganda and enabled them to globally connect with youths across the globe. The study recommends sensitisation, business skills training as well as adult and distant education opportunities for the youthful motorcycle drivers.
\end{abstract}

Boda-boda, Youth Employment and Globalisation in Uganda

\section{INTRODUCTION:}

Although Africa has enjoyed about twenty-five years of sustained economic growth with a steady rise of Per capita income, this growth has not resulted in job creation for the nationals (Page 2012). With the lowest chances of getting jobs into the formal sector (Nyachieo 2013), the youths are the most adversely affected by the mismatch between economic growth and job creation. To fill the job void, many youths in Uganda have taken to Boda-boda transport business.

Boda-boda is a popular term in East Africa which originally referred exclusively to bicycle transporters but has, in recent years, been expanded to cover motorcycle taxis as well (Raynor 2014). The term is a corruption of the expression 'border to border'. The word was coined by cyclists who used to ferry passengers and goods through the Kenya-Uganda border. They would shout 'border to border' to draw potential customers who needed their services between the border posts of Uganda and Kenya (Omolo Tom Odera 2015). With time, "border to border" with reference to the no man's land between Uganda and Kenya became "bodaboda" (Smith 2015). The $9^{\text {th }}$ edition of Oxford English Dictionary defines boda-boda as "a type of motorcycle or bicycle with a space for a passenger or for carrying goods, often used as a taxi."

Boda boda, thus, began as a bicycle taxi which transported both passengers and goods (Mutiso, 2010) across international borders of Uganda and Kenya in Busia and Malaba Towns. It became famous during the time of Magendo (Black Market) when Idi Amin was president of Uganda (Goodfellow 2015). It was necessary to use bicycles to ferry illegally exported goods like coffee. Any motorised transport system would alert security personnel and have the transporters and the transported arrested or shot.
From the Uganda-Kenya border towns of Malaba and Busia, boda-boda transport business spread to the borders with Congo, Rwanda, Tanzania and Sudan. Eventually the transport business gained grounds in Kampala City, other towns and urban centres of Uganda. Today, boda-boda is the most popular means of transport in all urban centres of Uganda (Smith 2015, Kigambo 2017). It is also the most commonly used means of transporting agricultural produce from the farm to the markets throughout Uganda.

This paper discusses the role of boda-boda transport industry in solving the problem of unemployment among the youths in Uganda. A youth-focused qualitative participatory methodology was applied. The author interviewed seventeen boda-boda drivers in Uganda and thirty-four of their family members to establish how this transport business has impacted on employment opportunities and the financial independence of youths. The paper also answers the puzzling question of why young people prefer this business relative to agriculture which is the backbone of Uganda's economy.

Boda-boda transport gained grounds in different towns and villages of Uganda at different times. From Malaba and Busia in eastern Uganda where the business began, it spread to nearby towns like Tororo and Iganga. Northern Uganda was the last to undertake boda-boda business. The twenty year armed conflict from 1986 to 2006 was responsible for the introduction of this business because it restricted other opportunities for youthful people to engage in economically viable activities. More especially, the war confined the entire population of northern Uganda into internally displaced persons' (IDP) camps where the boda-boda business started.

\section{IDPs Youths and Boda-boda business}

Originally the people of northern Uganda especially the Acholi did not want to carry anybody or anybody's luggage for 
money. There was news that in Lira people young men were transporting people and goods for pay. The Acholi did not approve of this. If you asked a man to transport you or your luggage, he would retort "an a boyi ni?" (Am I your servant?). The history of this can be traced to the colonial period when European officials made Africans carry them and their goods. They called the person providing poterage to them "boy". Carrying anybody other than a child or the sick became despicable and has remained so to date. Deplorable conditions in the IDP camps, however, forced Acholi men to acquiesce.

Internally displaced persons' (IDP) camps grew in northern Uganda almost throughout the twenty or so years of civil war between the Lord's Resistance Army (LRA) and the government of Uganda. There were limited job opportunities in the IDP camps and this made the most agile group of humans-the youths not only to be idle but also financially handicapped.

Before the establishment of camps, the youth in northern Uganda were actively engaged in agriculture and animal husbandry. Since nobody was permitted to move out of the camps and due to the loss of animals to cattle rustlers and armed fighters around the same period, the youth had to find alternative economic activities. They began by transporting people within the camps on bicycle taxis. In the IDP camps:

Most youth earn only a meagre income from the casual labour and odd jobs that form the basis of employment in camp economies... It is far from clear that camp economies can support more kiosks, more tailors, more charcoal production, or more bicycle taxis (Blattman and Annan 2008).

Around this time the national army's mobile brigade was active in northern Uganda. Traders supplied the soldiers with drinks, food stuff etc and there were hundreds of wives of soldiers who followed their husbands wherever they went. Transporting these women and traders was the preoccupation of the youthful boda-boda drivers. They used bicycle taxis but with time, motorcycles emerged and have since dominated the boda-boda transport system.

Matters were made worse by the death or abduction of many men during the war in northern Uganda. Eighteen percent of children in Uganda are orphans (Evans, 2012). Many of the children in the IDP camps were orphans or those whose parents had been abducted by rebels. In many African societies, older siblings are expected to look after their younger siblings without adult supervision (Evans, 2012). It dawned upon the elder siblings in the IDP camps that they had to find means of fending for their orphaned brothers and sisters. They started by providing transport business using the bicycles left by their dead or abducted fathers.
Child headed families became phenomenon in northern Uganda around the same time due to HIV/AIDS scourge and the LRA war. Traditional social systems that supported orphans broke down during the camps as people no longer lived in the neighbourhood of their uncles, aunties and cousins. This is why there were child boda-boda drivers during the camp life. The advantage is that there is no regulation and no permit is required to operate a boda-boda especially in the camps that never even had a police station.

Demand for boda-boda transport increased in the camps due to the high death rates then. Many African societies have ancestral burial grounds so those who died in the IDP camps had to be buried in their respective burial grounds. Although movements outside the camps were forbidden, permission could be easily got if the exit was for burial purposes and involving a few people. Even the rebels never attacked mourners going to bury their dead. Among the Acholi, there are several taboos associated with attacking or harassing people in mourning.

A dead body could be ferried easily to the burial grounds by means of boda-doda after all, the roads were not motorable so even if there were vehicles to transport the dead and mourners, the roads were impassable except for the motorcycles. Thus, it was during the camps that dead bodies were carried on motorcycle and bicycles. Before that, bodies were stretched home or transported in vehicles.

To date boda-bodas are sometimes used to transport the sick as well as the dead all over Uganda. It's the cheapest, reliable, convenient and most mobile means of transport available. Hours or even minutes after the death of somebody a boda-boda is called to transport the body home since the embalming means are not available in most of rural Uganda. Boda-boda riders charge four times the rate of transporting a person on dead body. Besides the amount charged, culture requires that the driver is cleansed with a chicken that he alone can rear or eat. One who transports a dead body returns with a chicken and money.

Expectant mothers became the most important clients of the boda-boda drivers and have remained so even after the camps were disbanded. Since traditional birth attendants have been banned all mothers have to attend antenatal care and deliver their babies in a health facility, which in rural, Uganda mean Health Centre II for parishes and Health Centre III for sub-counties. Boda-boda service providers are called any time labour begins even at night and many babies have been given the names of the boda-boda transporter who rushed the mother to the nearby health facility.

There was negative rating for camp leaders in whose zone a mother delivered outside a health facility. For this matter, camp leaders mobilised expectant mothers for antenatal care and to have their babies delivered at a health facility. The job of transporting 
them belonged to the youthful boda-boda drivers. For most of the time during camp life and in some villages up to today, there are Non-governmental Organisations that paid for transporting expectant mothers to the nearby health facility for delivery and back home with their baby. Boda-boda drivers bagged this money.

\section{Boda-Boda and Rural-Urban migration}

Faced with globalisation and the changing trend of livelihoods, the youth of northern Uganda have found it life-coping strategy to migrate to urban centres for much paying jobs than agriculture. Historically, northern Uganda was known for producing such crops as cotton, tobacco and cereals for domestic consumption. Cotton and tobacco take long to mature and are labour intensive.

Inspired by modern gadgets such as radios, smart phones, watches and sports betting facilities, the youth can no longer waits for six months for tobacco to mature, cure and sell before they earn much needed money. The remedy is in boda-boda business that earns money instantly. Oloya in Gulu Municipality migrated from Palaro Sub-county, some sixty kilometres north of the town. He says boda-boda enables him to rent a cemented house and own television set, things the youths who live in Palaro can't afford.

Matters are made worse by the high birth and growth rates in Uganda. Uganda's population growth rate is 3.6 percent per annum. This population cannot match the slow pace of social services' growth in the rural areas. The easily available option is to migrate to the town where services demanded by youths are available including electricity, night clubs, sport betting houses, internet and telephone networks. This is why it has been stated that:

In such rapidly growing economies as Ethiopia, Ghana, Tanzania and Uganda migration in response to rapid growth has resulted in urban youth unemployment rates of more than 15 percent (Page 2012).

The youth migrate to the towns in search of jobs but in most cases fail to secure them because of low education, tribalism and corruption. The youths from rural places neither have the money to bribe their way out nor understand the language of corruption. This is why they resort to boda-boda business because it does not require high level connections to start it.

For the females, the solution is prostitution which now has a huge market due to the availability of many unmarried youths and the business community. Prostitution is as fast earning as bodaboda. One first pays the prostitute before she provides the service. "Akok kede icinga" is the slang with which the prostitutes are known in Gulu Municipality. It literally means "I will groan with the money in my hands".

The other advantage for boda-boda business is that public transport throughout Uganda is largely unregulated. Goodfellow
(2015) has opined that "Uganda has both one of the highest urban growth rates in Africa and among the least regulated urban transport sectors". The problem began way back in 1990s when Uganda Cooperative Transport Union (UCTU) was privatized as a requirement of the Structural Adjustment Programs policy.

Thus, as of now, anybody can start a transport business including buses, minibuses, taxis and boda-boda. The rich especially those who belong tto the ruling party in Uganda own fleets of buses, the working class and business community can afford to operate a few motorised taxis while the youth dominate the boda-boda. Hence:

By 2010, boda-bodas were omnipresent in Kampala city, and their drivers were widely considered to constitute an urban underclass of "rogues" and criminals that the state was powerless to control them (Goodfellow 2015).

Criminality involving the boda-boda drivers is multifaceted. First the bodaboda drivers mostly hire the motorcycles and pay the owners on a daily basis. There is high temptation to own motorcycle so that the profit is not shared. Consequently some boda-boda drivers attempt to still a motorcycle from one town and drive it over night to another where they will operate as proud driver and owner of the motorcycle.

But the boda-boda drivers are also hired by criminals to aid their activities in the suburbs of Uganda's towns. The boda-bodas are preferred because they increase manoeuvrability, speed and efficiency. Many of the high level murder and assassinations in Uganda were carried out by men riding on motorcycles (Kasozi 2019). This includes the murder of Assistant Inspector General of Police (AIGP) Felix Kaweesi, Honorable Abiriga, the Member of Parliament of Arua Municipality and Major Kigundu a, senior UPDF officer. In all cases, the assassins disappeared on motorcycles within minutes of shooting their victims.

Young married men are under pressure from their spouses to migrate to urban centres where standards of living are better. Formerly the youth would claim lack of employment in the towns and cities but today, this can't be an excuse because a youth can loan a motorcycle from another and live comfortably before buying their own. There is also the case of youth working hard for a year in the villages and saving money to buy a motorcycle.

Brick laying is one such activity, another is agriculture. Simsim is a common crop in northern Uganda. Originally a food crop but today it is one of the most popular cash crops. Simsim is exported to the Arab world, china and United Kingdom among others where it is used in the aviation industry. Otema who operates three bodabodas in Kitgum Municipality planted four acres of simsim in 2014 earning 4,800,000 shillings in December. He bought one motorcycle and started with it a boda-boda business at Oryang Ward. Profits from this motorcycle made him by another in 2017 
and a third in march 2019. Today he drives one and hires out two of his motorcycles in total earning one hundred twenty thousand Shillings a day $(120,000)$. This is about 31 USD.

\section{Boda-boda and electioneering}

The busiest period for boda-boda business is the time of elections and electioneering. Voter apathy in Uganda means that the Middle Class is disinterested in political rallies and voting. This leaves the youth and slum dwellers to dominate the campaigns and voting. The youthful boda-boda drivers come in handy to feel the void left by the elites.

The boda-boda drivers take part not only in transporting people to the rallies and polling stations during voting, they also escort candidates during nomination. The more boda-boda drivers accompany a candidate, the greater the chance of winning. In 2001 President Yoweri Museveni rode to nominations grounds in Kampala on a boda-boda and this was copied by many other candidates in different parts of Uganda. Since that time President Yoweri Museveni has frequently used boda-boda services during his campaigns (Raynor 2014) in all corners of Uganda.

Normally, the boda-boda drivers are mobilised by the leaders to support specific candidates or work for them during the time of nominations, campaigns and voting. This is why the leaders of boda-boda associations all over Uganda are politically and economically powerful people. Every district in Uganda has a boda-boda association with an elected executive committee headed by one of the most popular drivers in the district. Then every stage has a leader, also elected. In this way, the boda-boda drivers are well organised and highly dependable for political manoeuvres.

Hence politicians normally begin by befriending the bodaboda association leaders mostly by way of cash donations. When this happens, the boda-boda leader then pledges loyalty and the support of his members to the respective politician. On one occasion:

The Chairman of Mbarara Municipality Boda-boda Movement Association, Mr. Ben Muhwezi, saluted the President for enabling them to execute their work in a good secure environment. He said that they were committed to ensuring that the country continues progressing. He pledged their loyalty and promised to support President Museveni during the 2016 elections and presented him a specially designed Tee-shirt to be used in the region when campaigns start (PPU 2015)

In this particular case, the president had organised a rally in Mbarara Municipality and, as usual, the Chair of local boda-boda association was given opportunity to greet the people assembled. The meeting took place in 2015 at a time when preparations were underway for the 2016 presidential elections which Yoweri Museveni won.

Politicians are well aware that Uganda is the country with the second lowest median age in the world and that formal sector youth employment rates are below $30 \%$ (UN 2017). Any monetary or job promises to the youth means winning their hearts and this is easily translatable into more votes than the opponent's who fail to offer anything to the young people. All over Uganda, boda-bodas are hired to popularise political meetings with the drivers moving around in huge convoys causing quite a stir with their hooting (Kigambo 2017).

Regrettably the boda-boda drivers have not learnt a lesson from the previous empty promises. Each time presidential and parliamentary elections are held, which for Uganda, is every five years as provided for by the 1995 constitution, politicians employ the boda-bodas to work for them. Some are hired for a month, others a week and the majority, daily. There is hardly any politician in Uganda, local or national, who wins elections without the support of the boda-boda drivers. This is what a Boda-boda chairman in Kampala told Titeca (2014):

For the politicians, we are important! We are political capital! If you need someone to chant, if you need advertisers, you just call us. We can market persons, we can teach about these persons! ... And we are too many! We can mobilise a big number!

Boda-boda, therefore, provides the youth with both short term and long term employment. In the short term, boda-boda drivers are hired for purposes of electioneering. They escort candidates to all campaign rallies from the time of nomination to voting. This normally takes three months. The rich politicians buy their own motorcycles and recruit young people to drive them. When elections are over, the bikes are then hired for boda-boda purposes.

In Gulu District, Honourable Achire Christopher depended heavily on boda-boda drivers to win several elections. He began as chairman LC I of a village, then became chairman of Bardege Division, later Mayor of Gulu Municipality and finally, member of parliament for Gulu Municipality. He won all these elections riding on the popularity garnered as proprietor of a company that imported motorcycles and loaned them to youths interested in the boda-boda business. In one occasion in 2010, Acire Cristopher donated three hundred motorcycles to youths of different subcounties of Gulu District. He was seen as the only businessman bent on ending youth unemployment. Little wonder that the next year he won the Gulu Municipality parliamentary elections with a landslide margin. He even beat the ruling party's candidate who was heavily financed by the government.

Hon. Acire's fortunes fell when he became a member of parliament in 2011. He could not effectively supervise his 
motorcycle business. Eventually the business collapsed and the role of loaning motorcycles to interested youths was taken over by Centenary Bank. When Christopher Acire stood for parliamentary elections again in 2016, the boda-boda drivers were no longer on his side and, not surprisingly, he lost to Hon. Okumu Reagan. His previous victories hinged on the support of Boda-boda drivers whom he supplied motorcycles. Nothing caused his popularity more that the motorbikes. As soon as his motorcycle business collapsed, the popularity also waned.

When it was reported recently that President Yoweri Museveni had directed that the boda-boda drivers should leave Kampala City Business centre to give way to tricycles and omni-buses that carry many people as a way of reducing congestion, a disclaimer was quickly offered:

However, Mr Museveni has in the past worked well with boda bodas, among other things, he blocked Kampala Capital City Authority (KCCA) from kicking them out of the central business district in 2015 (Bagala 2018)

The disclaimer was necessary to keep the boda-boda support to the side of the ruling party. It was important to remind the bodaboda drivers that the president is still on their side in spite of the plan to send them away from the city centre. This means that any decision on a policy that directly affects the boda-boda business has to be taken carefully

\section{Boda-boda and youth employment}

With a high population growth rate of 3.2 percent per annum, Uganda is facing a painful youth protuberance more so because close to 78 percent of Uganda's population is below the age of thirty (Ahaibwe, Ahaibwe and Mayanja 2013). Like in most economies across the globe, Ugandan youths are among the first to lose their job. This is because they are either semi-skilled or unskilled. This setback makes it particularly difficult for young people to get another job once they lose it (Scarpetta, Sonnet, and Manfredi 2010).

Worse still, low-skilled youth, who face multiple barriers in finding and retaining work, are at high risk of long-term inactivity and exclusion (Scarpetta, Sonnet, and Manfredi 2010). Once they lose their jobs the youth begin to suffer exclusion during that time when they are inactive. They are excluded by their peers due to the inability to match with the trend of the time. The urban youth is heavily dependent on money needed for phone and internet airtime, transport, feeding, housing etc. Hence losing a job is more painful to a youth than an older person because the latter may have made investments that they fall back to when dismissed from a job.

Although most youth jobs are temporary, youth unemployment is more responsive to the business cycle than adult unemployment
(Scarpetta, Sonnet, and Manfredi 2010). One reason is the high number of the youths, the second is the nature of work they do that involve physical energy like the Jua kali (metal fabrication). Mass unemployment of youths means low revenue for the government as well since Pay as you earn (PAYE) is one of the greatest sources of revenue for the government of Uganda.

Despite the importance of youth employment, many of the Ugandan youth are often out of work for various reasons including distortions in the economy. First, the government of Uganda has "over privatised and liberalized the transport sector" (Goodfellow 2015) and has not set standards of requirements that would ensure citizens are able to participate fully in the economy (Magelah and Ntambirweki- Karugonjo 2014). But liberalisation of the economy helped in the globalisation of the Ugandan youth in particular (Kate 2016). Privatisation and liberalisation in Uganda began in the late 1980s as a World Bank condition and intensified in the 1990s with all the parastatals that were created in the first government of Milton Obote and General Idi Amin privatised and the market opened for competition.

Today, Uganda is a much more informal economy with casual labour, self-employed production and services accounting for roughly $60 \%$ of cash-earning activities (Bryceson, Mbara and Dac Maunder 2003). This is why the boda-boda business has mushroomed in the country. True, the return of Asians expelled in the 1972 on the invitation of current president has rejuvenated some industries but the fact still remains that although some young people are able to gain employment in the formal economy, especially in growing sectors such as tourism, many have to create jobs for themselves (Gough, Langevang and Owusu 2013).

Although the return of Asians who now dominate the service as well as the manufacturing industries in Uganda has led to the opening of job opportunities, a growing mass of unskilled, young workers are still failing to find work in manufacturing and service sectors. The reason is that these sectors are consisting mainly of small-scale firms. Uganda like most developing countries has de-industrialized (Page 2012). This is contrary to the situation in other economies elsewhere in the world. Thus, the rates of unemployment and underemployment are especially high for young people, which present challenges not only for the youth themselves but also for their families and society in general (Gough, Langevang and Owusu 2013).

Realising that that the youth are restlessly looking for jobs yet are a significant political force, the government of Uganda with the help of development partners has undertaken a number of projects including road construction, building of hydro electricity power dams and provision of tax holidays for manufacturing firms. In spite of this there is a disturbing mismatch between the needs of youth and the programs offered by government and development partners (Annan, Blattman and Horton 2006). 
Since youths have been simultaneously the primary victims and the primary actors in the two-decade long war in northern Uganda (Annan, Blattman and Horton 2006), their employment records suffered the most. Both the Lord's Resistance Army (LRA) and the government forces targeted the young people for their fighting forces. The national army of Uganda resorted to training and arming of militia when the war began but were demobilised when it ended. Likewise many of the abducted and trained fighters of the LRA were rescued by the national army and rehabilitated by NGOs like World Vision. The former combatants had only one job waiting for them-boda-boda business.

It's common knowledge in northern Uganda that the majority of Boda-boda drivers are dwong cen paco - the name with which former child soldiers of the LRA are known. Gulu youth Development Association began as an NGO to serve the interest of former child soldiers and has received funding from World Vision, Norwegian Refugee Council and several other international bodies to train youths in motorcycle driving and repairing as well as metal fabrication. Boys are trained and loaned motorcycles with a repayment period of up to three years. So, one clear way of absorbing the former child soldiers in northern Uganda has been boda-boda business.

The advantage with boda-boda is that it does not require a lot of skills or high levels of formal education. It also does not require a lot of capital and, for the case of post-war northern Uganda, there are rehabilitation programs that offer start up capital for young people. The government of Uganda has youth loan facility programs in which youths organised in a group of seven or more can access soft loans if they have a business plan. Banks like Centenary also have in place motorcycle loan facilities. The boda-boda business has absorbed northern Uganda youths because it's cheap to start and the loan repayment is easier because the business earns money on a daily basis compared to agriculture that can be ravaged by poor weather.

Indeed there is evidence that youth engagement in agriculture is declining amidst rising youth unemployment "yet the services and industrial sectors, despite growing at considerably faster rates, have not created enough jobs for the burgeoning youthful labour force" (Ahaibwe, Ahaibwe and Mayanja 2013). East Acholi, for instance, suffers from long droughts arising from the leeward effects of the Ethiopian highlands. Normally it's from December to May. When this occurs, the youth are discouraged from engaging in farming activities. Boda-boda becomes more attractive because there is no natural calamity that can befall it.

Another advantage with boda-boda is that there is no gestation period. A youth who planted cotton or tobacco has to wait for six months to start earning money from it. Worse still, the cash crops are at times sold on credit. The monopoly buyers first have to export the crops before they pay the farmers. Boda-boda business, thus, has greater advantages over agriculture from the perspective of the youths. This is the reason agriculture is declining even in formerly agrarian districts of Uganda.

Instead boda-boda has emerged as a complementary sector for agriculture. The farmers sell their produce to middle men who transport them to the major markets in the towns or the sub-county headquarters. Given the impassability of the feeder roads and the high cost of hiring vehicles, the farmers and middlemen in the sale and distribution of agricultural produce have resorted to boda-boda to transport their cassava, sweet potatoes, cabbages, groundnuts, maize etc to the market.

It's not uncommon, therefore, to see boda-boda arriving early morning with vegetables such as tomatoes and cabbages to the markets in Gulu and Kitgum municipalities. Cerelenu Market in Gulu municipality is a hub for boda-boda vegetable transporters. Some of the boda-boda drivers are paid on a daily basis but others have been put on weekly and monthly pay. Mr. Latim, a renowned boda-boda in Cerelenu markets, boasts of earning a monthly pay higher than his educated wife who is a secondary school teacher.

In some cases, boda-boda have been reported to abet theft of farm produce. Small scale farming in Uganda is still done the traditional way where there are no security lights and security guards in the gardens. Just as the farmer is planning to start harvesting their crops, unscrupulous people invade the garden at night and harvest as much as the boda-boda can carry. The stolen crops are transported at night to the markets in trading centres, towns and municipalities. Lamwaka in Palabek Ogili Sub-county, mobilised women the traditional way to go help in trashing her simsim only to find thieves had done it the day before. They left about two kilos of simsim with the words "this is to help you plant more next year".

Thus, whether in urban or rural Uganda, boda-boda drivers dominate the transport industry (Bryceson, Mbara and Maunder 2003). In urban they transport passengers and merchandise from wholesalers to the shops of the retailers while in rural Uganda, they are for passengers and agricultural produce. There is the risk of failure to control the boda-boda such as by restricting them out of the central business district but the boda-boda are not to blame for this. Urban public transport became highly informalized in Uganda in recent following the collapse of Uganda Transport Cooperative Union (Goodfellow 2015). Since then there has been no attempt by government to take charge of the public transport systems. This has given chance to boda-boda drivers to operate the routes they choose at the time of their choice as well.

Rather than rebuke the boda-boda drivers for traffic offences and causing congestion, the authorities, aware of the political capital that the boda-boda men are, do commend them instead. For instance, the Presidential Press Unit (PPU) reported recently 
that President Yoweri Museveni commended Bodaboda drivers for their specialization and good role in the transport industry:

He made the comments yesterday at the Mbarara Booma Grounds when he addressed the members of the Mbarara Municipality Bodaboda Movement Association and wheelbarrow pushers. He pledged a donation of Shs. 100 million to boost the activities of Bodaboda riders (PPU 2015)

Such statement in support of boda-boda drivers is common and it mostly comes from politicians who ally with them to win presidential, parliamentary and district council elections.

Boda-Bodas have also been used to fill another gap in the formal transportation market namely emergency medical transportation (Raynor 2014). In fact, there are boda-boda ambulances in Uganda. People suffering from asthma, sickle cell complications and other chronic ailments have their boda-boda contacts who they call at short notice. Whenever the patients want to visit their doctors they call the boda-boda and pay higher than other passengers.

\section{Boda-boda and Globalisation of the Ugandan youth}

Much as transport is an important component in both rural and urban development programs and an enabling element for the achievement of Millennium Development Goals (Nyachieo 2013), it's also an easy way of global connections for the African youth. Most Ugandan youths cannot afford modern transport means like vehicles and aeroplanes but can readily afford boda-bodas to connect them to nearby urban centres where internet, mobile phone networks and cable television are available.

Another important contribution boda-boda business has made is in education. I interviewed Odong in Gulu Town. He grew up with a grandmother who was forced to locate to the municipality due to the fear of rebels. Odong was supported by an NGO from primary to secondary level. In Gulu University, he took up weekend section so he conducted boda-boda business from Monday to Thursday and went for classes from Friday to Sunday. He paid his university dues with the profit from boda-boda business and completed his degree in development Studies. The education that Odong received with the support of boda-boda business enabled him to connect with the rest of the youth via email and skype communication (Lefrere 2016).

Many youth engaged in boda-boda business own Smart Phones that they use for international communication and sport betting. Its a common site to see boda-boda motorcycles parked in front of betting houses like SportBet in Gulu, Kitgum and Kampala. These belong to boda-boda drivers who have come to claim their prizes having won it by betting using their Smart phones. Such youths would not have afforded Smart phones if they were never engaged in boda-boda business.

That the Africa's young and growing labour force is today increasingly viewed in a more constructive light by development agencies as well as investors (Kate 2016) is because of, among others, the ability of the urban youth to communicate with employers as well as investors across the world. I found Kinyera, a youthful boda-boda driver, who wanted to have his ancestral land hired, chatting with a potential client in India via face book. The dominant position in northern Uganda is to rent out land for two to three years but never to sell it.

The youths what don't own smart phones are still able to bet using computers at the offices of SportBet and other betting companies spread across Uganda. They jump on their motorcycles and rush to the nearest betting facility on Fridays, Saturdays and Sundays when the English Premiership, European Championship and Europa Leagues are playing. They chart on face book and bet with football fans in Europe. One can therefore say with certitude that boda-boda has not only created employment for the youth but has also enable them to communicate with fellow sports' fans in England and other countries where football is popular.

\section{The Risk Factor of Boda-boda}

Boda-boda drivers have not benefited from this business without costs. All over Uganda there are several risks involved in it. The most common is accident many of which are fatal. Surgery wards in all major hospitals including Mulago National Referral Hospital are filled with boda-boda accident victims. Over speeding, failure to obey traffic rules and driving under the influence of alcohol are the common causes of accident for bodabodas (Galukande, Jombwe, Fualal, and Gakwaya 2009). In Gulu District boda-boda injuries were the second commonest cause of physical injury. The first is Gender based violence (Kitara 2011, Smith 2015)).

The fact that boda-bodas travel long distances on lonely roads and at times at night makes them vulnerable to armed robbery. Lutalo (not real name) was clobbered, robbed of his motorcycle and left for dead. "It's the early morning breeze that made me gain consciousness" he says. He still has scars on his head as a stern reminder of the night two iron bar hit men attacked him after pretending to be passengers. Many however were not lucky, as they lost the motorcycle as well as their lives.

Since boda-bodas have been hired by criminals to rob banks, kill political or business rivals and still farm produce, they have also been suspected of people with criminal intentions and a good number have been beaten to death or shot by security forces. As Kigambo (2017) has said:

Boda bodas are today so common place, they are used for every imaginable scenario. Criminals use them 
as a means for a quick get away from crime scenes and equally, spouses are known to use them to trail and spy on cheating partners. Security agents too are known to use them for surveillance

When the deals for which they were hired don't go well and they are intercepted by police, the criminals as well as the bodaboda drivers are shot. The unfortunate bit of it is that many times the boda-boda drivers are unaware of the criminal intentions of their passengers. But boda-boda drivers are not innocent victims all the time. Abdullah Kitata, the head of Boda-boda Ten group that operated in Kampala and his brother engaged in criminal activities and were armed. Recently, he was found guilty of illegal possession of fire arms and harassment of people. He was convicted and sentenced for eight years in jail (Kasozi \& Kigongo 2019).

Likewise, many of them have been implicated in crime, arrested and imprisoned. The young boys are not always quick to detect criminal intentions of their passengers. Musiitwa was sent for a lady whom she delivered safely. The man who sent him later murdered the lady but a CCTV camera had captured Musiitwa's motorcycle registration details. Security personnel traced and arrested him. He has been jailed for abetting murder.

In some cases boda-boda confront each other especially when they belong to rival association. Although Kigambo (2017) has written that:

Boda boda riders are a law unto themselves, and swear by mob injustice. They have what one observer has called a "secret brotherhood with a code of honour." To touch one is to touch all.

Rival boda-boda associations always fight each other. At the Makerere University Main Gate, the boda-boda drivers operating there don't allow those that come from elsewhere to carry students coming out of the university. The boda-boda operators in neighbouring stages don't also allow the Makerere boda-bodas to carry passengers from their bases. This has occasionally led to fights among different boda-boda groups. Kigambo's opinion only applies when motor vehicle drivers attack boda-boda-drivers or when a boda-boda is knocked dead or injured by a motor vehicle.

\section{CONCLUSION}

Today, Boda-boda is the second highest employer in Uganda after agriculture (Magelah and Ntambirweki- Karugonjo 2014). It is even poised to take over agriculture in the near future as more youths get attracted to it because of the reasons that I have advanced in this paper. Boda-boda business is neither bogged down by poor whether nor does it require patience for up to six months before one starts to earn money as is the case with cash crops like tobacco and cotton.
Politically boda-boda is attractive since politicians hire them frequently for campaign purposes (Smith 2015). The leaders of the boda-boda remain political allies of those candidates that get elected. Boda-boda therefore creates better social capital than agriculture. After riding to Kololo Independence Grounds for his 2001 nomination on a boda boda, President yoweri Museveni turned the boda-boda drivers into a powerful political constituency (Goodfellow 2015).

Boda-boda are also used by different security agencies for raw intelligence gathering (Bagala 2018). A case in point is that of Abdallah Kitata whose boda-boda group was created, funded and controlled by General Kale Kayihura, the former Inspector General of Police (Kasozi \& Kigongo 2019). This association with high profile people in government and the intelligence gurus in Uganda makes boda-boda business quite attractive to the youth.

Since there has been a strong tendency towards deagrarianisation in the countryside and de-industrialisation in the cities, this paper argues that formal sector jobs have contracted. "As a result, a great deal of occupational reorientation has taken place" (Bryceson, Mbara and Dac Maunder 2003). The youths falling out of favour with agriculture and losing jobs as a result of the contraction of the formal employment sector are being increasingly absorbed in boda-boda transport business.

\section{REFERENCES}

Ahaibwe Gemma, Ahaibwe Swaibu and Mayanja Musa Lwanga (2013) Youth Engagement in Agriculture in Uganda: Challenges and Prospects. Economic Policy Research Centre, Research Series No. 106

Annan Jeannie, Blattman Christopher and Horton Roger (2006), The State of Youth and Youth Protection in Northern Uganda: Findings from the Survey for War Affected Youth. A Report for UNICEF Uganda

Bagala Andrew (2018) Government to kick bodas out of city, says Museveni. Daily Monitor 20/12/2018

Blattman Christopher and Annan Jeannie (2008) "Child combatants in northern Uganda: Reintegration myths and realities" in Muggah Robert, ed. Security and Post-Conflict Reconstruction: Dealing with Fighters in the Aftermath of War. Routledge. 103-126.

Bryceson, D. F., Mbara, T. C., Dac Maunder (2003) Livelihoods, Daily Mobility and Poverty In Sub Saharan Africa. Transport Review 2003. Vol. 23 (2): 177-96

Galukande M, Jombwe J, Fualal J, Gakwaya A (2009) Boda-boda Injuries a Health Problem and a Burden of Disease in Uganda: a Tertiary Hospital Survey. East and Central African Journal of Surgery Vol. 14 (2): 32-37

Goodfellow Tom (2015) Taming the "Rogue" Sector: Studying 
State Effectiveness in Africa through Informal Transport Politics. Comparative Politics, Vol. 47, No. 2: 127-147

Gough, K.V., Langevang, T. and Owusu, G., 2013. Youth employment in a globalising world. International Development Planning Re-view, 35 (2), pp. 91 - 102.

Evans, R. (2012) Sibling caringscapes: time-space practices of caring within youthheadedhouseholds in Tanzania and Uganda. Geoforum, 43 (4). pp. 824835. ISSN 00167185 doi: https://doi. org/10.1016/j.geoforum.2012.02.004 Available at http://centaur. reading.ac.uk/27842/

Kasozi Ephraim \& Kigongo Juliet (2019) Who is Kitatta, the NRM vigilante? Daily Monitor Tuesday May 142019

Kate Meagher (2016) The Scramble for Africans: Demography, Globalisation and Africa's Informal Labour Markets, The Journal of Development Studies, 52:4, 483-497, DOI: $10.1080 / 00220388.2015 .1126253$

Kigambo Gaaki (2017) Kampala: moving on boda boda power. The east African, Wednesday August 162017

Kitara David Lagoro (2011) Boda Boda Injuries in Gulu Regional Hospital, Northern Uganda. East and Central African Journal of Surgery Vol. 16 (2): 97-102

Lefrere Paul (2016) Competing Higher Education Futures in a Globalising World. European Journal of Education, Vol. 42, No.

2: pp. 201-212

Magelah Peter and Ntambirweki- Karugonjo Barbara (2014) Youth Unemployment and Job Creation In Uganda: Opportunities and Challenges. ACODE infosheet No. 26

Mutiso Wilson Kasyoki (2010) Boda boda' bicycle taxis and their role in urban transport systems: Case studies of Nakuru and Kisumu, Kenya. Msc. Civil Engineering, University of Cape Town Nyachieo M. Gladys Moraa (2013) Creating Employment through Transport; the Youth and Motorcycle (Boda Boda) in Kitengela, Kajiado County- Kenya. Research Journal in Organizational Psychology \& Educational Studies 2(4): 154-157

Omolo Tom Odera (2015) Boda-Boda Economy: Its Socioeconomic Impact on Rural Bondo. Bachelor of Social Services (UAS) thesis, Diaconia University of Applied Sciences, Helsinki.
Page, John (2012), Youth, Jobs, and Structural Change: Confronting Africa's "Employment Problem" Working Paper Series N 155 African Development Bank, Tunis, Tunisia.

PPU (2015) President Museveni commends Bodaboda riders for their specialization. Monday 2nd March 2015

Raynor, Bradley (2014) "Informal Transportation in Uganda: A Case Study of the Boda Boda". Independent Study Project (ISP) Collection. 1923. https://digitalcollections.sit.edu/isp_ collection/1923

Smith Chris (2015) Boda-bodas: The bikes that keep Uganda moving. Newsbeat $6^{\text {th }}$ February 2015

Scarpetta, S., Sonnet, A. and Manfredi, T. (2010), "Rising Youth Unemployment During The Crisis: How to Prevent Negative Longterm Consequences on a Generation?" OECD Social, Employment and Migration Working Papers, No. 106, OECD Publishing. doi: $10.1787 / 5 \mathrm{kmh} 79 \mathrm{zb} 2 \mathrm{mmv}$-en

Titeca, Kristof (2014) 'The Commercialization of Uganda's 2011 Election in the Urban Informal Economy: Money, Boda-Bodas and Market Vendors', in: Perrot, S.; Makara, S.; Lafargue, J.; Fouéré, M.A. (eds.) Elections in a hybrid regime. Revisiting the 2011 polls. Kampala: Fountain publishers, pp.178-207.

UN DESA POPULATION DIVISION (2017) World Population Prospects: The 2017 Revision Population Database

\section{RESUME}

Dr. Charles Amone is an Associate Professor of History at Kyambogo University in Kampala. He holds a Ph. D in History of Makerere University. He is a former Fulbright Scholar of the University of Millersville in Pennsylvania, USA, a former Fellow of the Institute of Languages and Communication of the University of Southern Denmark, former Fellow of the Institute of Development Policy (IOB) of the University of Antwerp in Belgium and former Fellow of the Global Health Institute, Belgium. Dr. Amone specialises in cultural and ethnic studies in which he has over thirty publications.

Citation: Charles Amone "Boda-boda, Youth Employment and Globalisation in Uganda". American Research Journal of History and Culture, Vol 7, no. 1, 2021, pp. 1-9.

Copyright @ 2021 Charles Amone, This is an open access article distributed under the Creative Commons Attribution License, which permits unrestricted use, distribution, and reproduction in any medium, provided the original work is properly cited. 